\title{
Fiber Optic Biosensor for the Detection of Cd in Milk
}

\author{
Neelam Verma*, Sachin Kumar and Hardeep Kaur \\ Department of Biotechnology, Punjabi University, Patiala, India
}

\begin{abstract}
A novel absorption-transmission based, miniaturized fiber optic biosensor has been developed for the detection of cadmium in milk. Biosensor constitutes Bacillus badius whole cells with phenol red as an indicator co-immobilized onto circular plastic discs with sol-gel approach and a fiber optic transducer system. Inhibition of urease enzyme by cadmium ion has been used as bioassay principle in the study. The detection limit of $0.1 \mu \mathrm{g} / \mathrm{l}$ has been achieved. Sample volume could be miniaturized to $10 \mu \mathrm{l}$; miniaturization of sample volume to this level has never been cited in literature. Storage stability of biocomponent was found to be more than 90 days when stored at $4^{\circ} \mathrm{C}$ in $10 \%$ glycerol. Conclusively the study resulted in development of a quick, reliable, miniaturized biosensor with lower detection limit and longer storage stability.
\end{abstract}

Keywords: Biosensor; Cadmium; Milk; Bacillus badius; Urease

\section{Introduction}

Milk and dairy products are a source of many valuable nutrients and minerals for human. In recent years, there has been growing interest in microelements, as their presence in food materials is the indicator of qualitative parameters. Trace metals such as $\mathrm{Pb}, \mathrm{Cd}, \mathrm{Zn}$, $\mathrm{Cu}, \mathrm{Cr}$ and $\mathrm{As}$ are potential bioaccumulative toxins in the production system of milk and dairy products [1]. Cadmium may enter the body through food, water, air or absorption through the skin however food and smoking are the main source of exposure in the nonoccupationally exposed population [2]. Cadmium absorption after dietary exposure in humans is relatively low (3-5\%) but cadmium is efficiently retained in the kidney and liver in the human body, with a very long biological half-life ranging from 10 to 30 years. Cadmium is primarily toxic to the kidney, especially to the proximal tubular cells where it accumulates over time and may cause renal dysfunction. Cadmium can also cause bone demineralization, either through direct bone damage or indirectly as a result of renal dysfunction [3].

Lead and cadmium are major contaminant in milk, the statewide survey in California had shown that mean concentration of cadmium in 320 raw milk samples was $6 \mu \mathrm{g} / \mathrm{kg}$ [4]. The average cadmium content in milk from different farm was found to be $0-20 \mu \mathrm{g} / \mathrm{l}$ as reviewed by Valiukenaite et al. [5]. Level of cadmium in the milk of lactating cows reared around lead-zinc smelter and steel manufacturing plant has been recorded as high as $0.23 \pm 0.02 \mu \mathrm{g} / \mathrm{ml}[6]$.

Studies suggest that bioavailability of cadmium is different for different food source. Marginal deficiencies of essential nutrients like $\mathrm{Zn}$ and $\mathrm{Fe}$ enhance the $\mathrm{Cd}$ absorption as much as tenfold from the diets containing low $\mathrm{Cd}$ concentrations similar to that consumed by populations. As it has been studied that cadmium absorption is increased with an increase of fat and protein content, milk being rich in fat and protein and usually devoid of iron and zinc, is a potential contender for $\mathrm{Cd}$ exposure to humans $[7,8]$.

The standard techniques for trace heavy-metal analysis in milk include Atomic Absorption Spectrometry (AAS) and Inductively Coupled Plasma-Mass Spectrometry (ICPMS). Differential pulse polarographic determination of cadmium, lead and copper in milk has been studied by Tokusoglu et al. [9]. But these methods require expensive equipment which cannot be used in the field. Moreover virtually all of the methods involve complicated and time-consuming sample treatment and pre-concentration steps that can be carried out only by trained professionals. This prohibits screening for heavy metals at various stages of food production and hinders the objective of preventing heavy metal contamination as early as possible in the production chain.

In the recent years application of biosensors for detecting and quantifying heavy metal has been the subject of intense research all over the world [10]. Current study is an effort to develop a disposable optical biosensor for the detection of cadmium in milk.

\section{Material \& Methods}

All the chemicals and reagent used in the study were of analytical grade. Maya 2000 series spectrometer, fiber optic probe from Ocean Optics has been used in the study.

\section{Preparation of culture}

Bacillus badius, MTCC 8082, novel isolate of Biosensor Technology Lab, Dept. of Biotechnology, Punjabi University Patiala isolated from urea rich soil near National Fertilizer Limited (NFL), Nangal, India, cultured in the nutrient medium containing $10 \mathrm{~g}$ Beef Extract, $10 \mathrm{~g}$ Peptone, $5 \mathrm{~g}$ Sodium Chloride and 25gUrea/l, $\mathrm{pH}$ of the medium was kept 7.0-7.5. Culture was incubated for $21 \mathrm{hrs}$ at $37^{\circ} \mathrm{C}$ at $200 \mathrm{rpm}$; average OD of the culture was found to be 0.9 at $600 \mathrm{~nm}$ of $50 \mathrm{ml}$ broth.

\section{Construction of biocomponent}

$21 \mathrm{~h}$ grown culture of $B$. badius was centrifuged at $5000 \mathrm{rpm}$ for $20 \mathrm{~min}$ at $4^{\circ} \mathrm{C}$, the pellet of cells from $50 \mathrm{ml}$ culture was taken in $250 \mu \mathrm{l}$ of $10 \%$ glycerol. $50 \mu \mathrm{l}$ of extracted cells mixed with $600 \mu \mathrm{l}$ alcohol, $50 \mu \mathrm{l}$ Tetra Methyl Ortho Silicate (TMOS), $10 \mu \mathrm{l} \mathrm{NaOH}(5 \mathrm{mM})$ and $20 \mu \mathrm{l}$ phenol red $(1.25 \mathrm{mg} / \mathrm{ml}$ in $50 \%$ Ethanol). $10 \mu \mathrm{l}$ of the mixture was introduced on to the circular transparent plastic discs with a diameter of $5 \mathrm{~mm}$ (Figure 1). The discs thus prepared were incubated for $1 \mathrm{hr}$ at $4^{\circ} \mathrm{C}$ for immobilization. These discs were used for further study.

*Corresponding author: Neelam Verma, Department of Biotechnology, Punjabi University, Patiala, India, Tel: +91-175-3046263; Fax: +91-175- 2286412, 2283073 E-mail: verma.neelam2@gmail.com

Received October 05, 2010; Accepted October 19, 2010; Published October 20, 2010

Citation: Verma N, Kumar S, Kaur H (2010) Fiber Optic Biosensor for the Detection of Cd in Milk. J Biosens Bioelectron 1:102. doi:10.4172/2155-6210.1000102

Copyright: (c) 2010 Verma N, et al. This is an open-access article distributed unde the terms of the Creative Commons Attribution License, which permits unrestricted use, distribution, and reproduction in any medium, provided the original author and source are credited. 


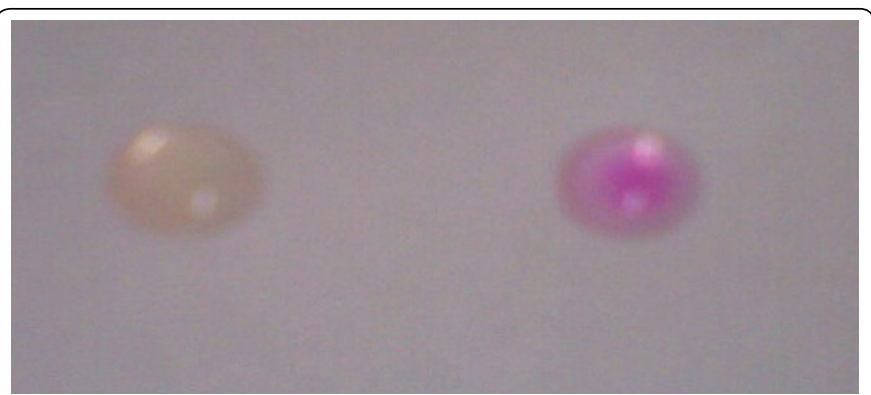

Figure 1: Picture showing the discs (Biocomponent), activity of urease with change in colour i.e. yellowish in absence of urea (left) and dark pink after adding $10 \mu \mathrm{l}$ of $2 \mathrm{M}$ urea (right).

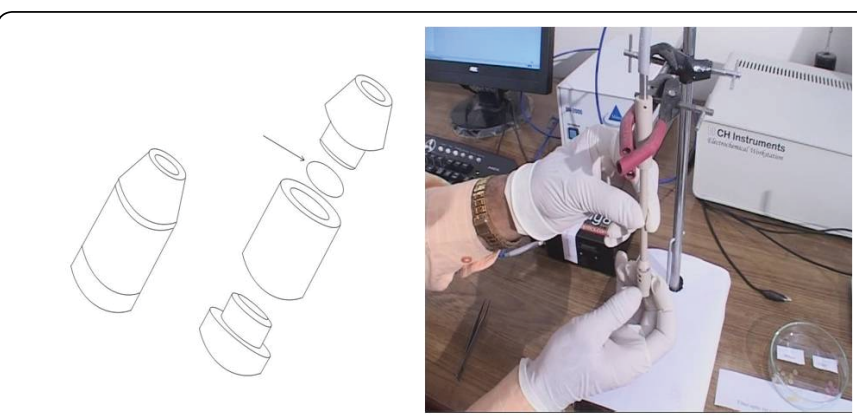

Figure 2: Different parts of fiber optic tip, arrow indicating the position of plastic disc (biocomponent) used for the study, adjustment of disc in the fiber optic tip.

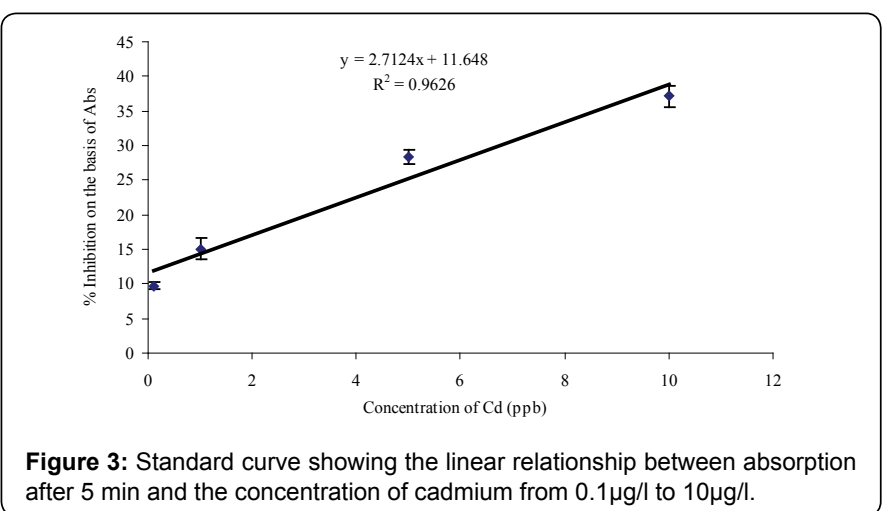

\section{Application \& reliability check}

For the study plastic discs with immobilized biocomponent were set within the fiber optic tip (Figure 2). $10 \mu \mathrm{l}$ of $2 \mathrm{M}$ urea carrying different concentration of $\mathrm{Cd}(0.1 \mu \mathrm{g} / \mathrm{l}$ to $10 \mu \mathrm{g} / \mathrm{l})$ was introduced on to the disc. Baseline was set with $10 \mu \mathrm{l}$ of distilled water. After wavelength scan $555 \mathrm{~nm}$ was found to be $\lambda_{\text {max }}$ therefore the absorption was studied at $555 \mathrm{~nm}$ for $5 \mathrm{~min}$. Initially the absorbance was studied up to $10 \mathrm{~min}$ but after $5 \mathrm{~min}$ there was no appreciable change in absorbance was found. Hence optimized response time is $5 \mathrm{~min}$.

The developed biosensor was used to monitor $\mathrm{Cd}^{2+}$ in milk samples from Verka milk booth. Acid extraction of $\mathrm{Cd}^{2+}$ from milk samples was achieved by adding 2-3 drops of $\mathrm{HNO}_{3}$ acid in $10 \mathrm{ml}$ of milk sample followed by centrifugation at $5000 \mathrm{rpm}$ for $20 \mathrm{~min}$ at $4^{\circ} \mathrm{C}$. The supernatant was taken, $\mathrm{pH}$ was brought back to 7 , added urea to have a final concentration of $2 \mathrm{M}$ and $10 \mu \mathrm{l}$ from this introduced to the disc for the study. Reliability of the developed biosensor was checked with the spiked sample by standard addition method. Spiking was made by adding $1 \mathrm{ml}$ of $20 \mu \mathrm{g} / \mathrm{l} \mathrm{Cd}$ to $1 \mathrm{ml}$ of acid extracted milk sample (whose concentration was found to be $8.1 \mu \mathrm{g} / \mathrm{l}$ ) then urea was added to have $2 \mathrm{M}$ final concentration of urea and then $10 \mu \mathrm{l}$ from this was introduced onto the disc. Response of the developed biosensor to a higher concentration was also checked with $1.0 \mathrm{mg} / \mathrm{l} \mathrm{Cd}$. Validation of the developed biosensor was also carried out with conventional method i.e. atomic absorption Spectrophotometer (AAS). Storage stability of the biosensor was also checked when stored at $4^{\circ} \mathrm{C}$ in $10 \%$ glycerol.

\section{Results and Discussion}

A good correlation was found between absorption and the concentration of cadmium in the samples, a linear relation was found between $0.1 \mu \mathrm{gCd} / \mathrm{l}$ to $10 \mu \mathrm{gCd} / \mathrm{l}$. Conc. of $\mathrm{Cd}$ in the milk sample was found to be $8.1 \mu \mathrm{g} / \mathrm{l}$ as calculated from the graph (Figure 3).

Increase in concentration of $\mathrm{Cd}$ resulted in the inhibition of urease activity and thereby decrease in production of ammonium ions, decrease in absorption at $555 \mathrm{~nm}$. Though linear relation was found between $0.1 \mu \mathrm{gCd} / \mathrm{l}$ to $10 \mu \mathrm{gCd} / \mathrm{l}$, convincing results have been shown even at high concentration i.e. $1.0 \mathrm{mg} / \mathrm{l}$, showed more than $90 \%$ inhibition (Table 1).

In spiked sample $\mathrm{Cd}$ was detected to be $13.32 \mu \mathrm{g} / \mathrm{l}$ for $14.05 \mu \mathrm{g} / \mathrm{l}$ hence reliability of biosensor is found to be as high as $94.8 \%$ (Table 2). Biocomponent was found to be stable for more than 90 days when stored at $4^{\circ} \mathrm{C}$ in $10 \%$ glycerol.

Biosensors for heavy metal, especially for Cd reported earlier includes Tauriainen et al. [11] that constructed a luminescent bacterial biosensor respond to cadmium at $3.3 \mathrm{n} \mathrm{mol} / \mathrm{l}$; the results are obtained with 2-3 hrs incubation. Biosensor developed in present study is rapid as well as sensitive to a lower concentration. May and Russell [12] developed a biosensor based on changes in structure of urease enzyme after binding with cadmium being the basis of surface plasmon resonance biosensing system. The enzyme was modified with $\mathrm{N}$-succinimidyl 3-(2-pyridylthiol) propionate (SPDP) to facilitate the formation of a self assembled monolayer of urease on the gold coated glass SPR sensor disk. It is this change of enzyme monolayer measured by SPR, which has been related to the cadmium ion concentration in the range of $0-10 \mathrm{mg} / \mathrm{l}$. Current study is novel and significant for its source of enzyme i.e. urease, bio-sensing system with a quick response time; having a significantly low detection limit $(0.1 \mu \mathrm{g} / \mathrm{l})$. A biosensor based on mammalian metallothionein for the detection of metal ions was developed by Wu and Lin [13], that detected the cadmium up to the range 2 to $10 \mu \mathrm{mol} / \mathrm{l}$. Low cost small size all-solid state $\mathrm{pH}$-urease electrodes useful for determination of heavy metals ions have been developed by means of screen printing, Cadmium was inhibiting at the conc. of $1 \mathrm{mM} / \mathrm{l}$ [14]. Our developed biosensor is much more sensitive.

A conductometric biosensor using immobilized Chlorella vulgaris microalgae was used as a bienzymatic biosensor with limit of detection $10 \mu \mathrm{g} / \mathrm{l}$ for $\mathrm{Cd}$ after $30 \mathrm{~min}$ long exposure based on alkaline phosophatase, acetyl choline transferase inhibition [15]. Our developed biosensor is faster as well as sensitive to a lower concentration. Liao et al. [16] developed a GFP based biosensor that responded to Cadmium $0.1 \mathrm{n} \mathrm{mol} \mathrm{l}^{-1}$ being the lowest detectable concentration with $2 \mathrm{hr}$ exposure. Haron and Ray [17] developed an optical biosensor for cadmium and lead by employing the technique of total reflection at the interface between $\mathrm{Si}_{3} \mathrm{~N}_{4}$ core and composite polyelectrolyte self-assembled (PESA) membrane containing cycloptetrachromotropylene (CTCT) as an indicator; achieved a detection limit as low as $1 \mu \mathrm{g} / \mathrm{l}$ for both the metals. Chong et al. [18] 
Citation: Verma N, Kumar S, Kaur H (2010) Fiber Optic Biosensor for the Detection of Cd in Milk. J Biosens Bioelectron 1:102. doi:10.4172/21556210.1000102

Page 3 of 3

\begin{tabular}{|c|c|c|c|c|c|c|c|}
\hline & Time (in minutes) & & & & & & $\%$ Inhibition on the \\
\hline & & 1 & 2 & 3 & 4 & 5 & basis of Abs at 5 minute \\
\hline & Control (2M Urea) & $0.95 \pm 0.01$ & $1.01 \pm 0.01$ & $1.09 \pm 0.02$ & $1.11 \pm 0.01$ & $1.13 \pm 0.01$ & $0.00 \pm 0.00$ \\
\hline$\varepsilon$ & $\mathrm{Cd}(0.1 \mu \mathrm{g} / \mathrm{l})$ & $0.88 \pm 0.01$ & $0.93 \pm 0.02$ & $0.98 \pm 0.01$ & $1.00 \pm 0.02$ & $1.02 \pm 0.01$ & $9.73 \pm 0.51$ \\
\hline L & $\mathrm{Cd}(1.0 \mu \mathrm{g} / \mathrm{l})$ & $0.76 \pm 0.02$ & $0.84 \pm 0.02$ & $0.88 \pm 0.02$ & $0.93 \pm 0.01$ & $0.96 \pm 0.03$ & $15.04 \pm 1.53$ \\
\hline Ln & $\mathrm{Cd}(5.0 \mu \mathrm{g} / \mathrm{l})$ & $0.69 \pm 0.01$ & $0.74 \pm 0.02$ & $0.75 \pm 0.03$ & $0.78 \pm 0.01$ & $0.81 \pm 0.02$ & $28.32 \pm 1.02$ \\
\hline @ & $\mathrm{Cd}(10.0 \mu \mathrm{g} / \mathrm{l})$ & $0.56 \pm 0.01$ & $0.59 \pm 0.02$ & $0.64 \pm 0.012$ & $0.69 \pm 0.02$ & $0.71 \pm 0.03$ & $37.17 \pm 1.53$ \\
\hline 듐 & $\mathrm{Cd}(1.0 \mathrm{mg} / \mathrm{l})$ & $0.00 \pm 0.0$ & $0.06 \pm 0.01$ & $0.10 \pm 0.02$ & $0.11 \pm 0.01$ & $0.11 \pm 0.02$ & $90.27 \pm 1.13$ \\
\hline "̄ & Milk & $0.67 \pm 0.01$ & $0.71 \pm 0.02$ & $0.72 \pm 0.02$ & $0.74 \pm 0.02$ & $0.75 \pm 0.04$ & $33.63 \pm 2.04$ \\
\hline 选 & Milk Spiked & $0.48 \pm 0.01$ & $0.50 \pm 0.02$ & $0.53 \pm 0.05$ & $0.56 \pm 0.02$ & $0.59 \pm 0.04$ & $47.78 \pm 2.04$ \\
\hline
\end{tabular}

Table 1: Absorption (Abs) of different samples taken up to $5 \mathrm{~min}$ at $555 \mathrm{~nm}$, \% inhibition on the basis of Abs at 5 minute

\begin{tabular}{|l|l|l|}
\hline Sample & Milk Sample & Spiked Milk Sample \\
\hline$\%$ Inhibition $^{\mathrm{a}}$ & $33.63 \pm 2.04$ & $47.78 \pm 2.04$ \\
\hline $\mathrm{Cd}(\mu \mathrm{g} / \mathrm{l})$ as analyzed by biosensor ${ }^{\mathrm{b}}$ ) & $8.1 \pm 0.44$ & $13.32 \pm 0.43$ \\
\hline $\mathrm{Cd}(\mu \mathrm{g} / \mathrm{l})$ Expected & $\mathrm{N} / \mathrm{A}$ & $14.05^{\mathrm{c}}$ \\
\hline $\mathrm{Cd}(\mu \mathrm{g} / \mathrm{l})$ as analyzed by AAS & 8.6 & 15.11 \\
\hline
\end{tabular}

Table 2: Concentration of cadmium in milk as analyzed with biosensor and validated with Atomic Absorption Spectrophotometer.

developed a whole cell biosensor on a diamond electrode. Unicellular microalgae Chlorella vulgaris was entrapped in the BSA membrane and immobilized directly onto the surface of a diamond electrode for heavy metal detection. The cell based diamond biosensor could attain a detection limit of $0.1 \mu \mathrm{g} / \mathrm{l}$ for cadmium. Application of developed biosensor has not been highlighted.

A novel transmission-based localized surface plasmon response (LSPR) fiber-optic probe has been developed to determine $\mathrm{Cd}$ ion concentration with a detection limit of $0.16 \mu \mathrm{g} / \mathrm{l}$ though the application The sensor retained $85 \%$ of its original activity after nine cycles of deactivation and reactivations; in addition sensor retains its activity up to $35 \mathrm{~d}$ at $4^{\circ} \mathrm{C}$ in $5 \% \mathrm{~d}$-(+)-trehalose [19]. Application of the developed biosensor has not been highlighted. In comparison our developed biosensor is more stable.

In comparison of biosensors developed earlier present biosensor has got many advantages like lower detection limit, quick response, storage stability, miniaturization of volume to a level of $10 \mu$ l never achieved before. The basis of fastness and sensitivity may be the novelty of the biocomponent as it all depends on the orientation of enzyme, structure and the quantity $[20,21]$.

\section{Conclusion}

Conclusively the study resulted in the development of a fast and reliable absorption-transmission based fiber optic biosensor with a lower detection limit for cadmium equivalent in milk. Further specificity can be achieved by passing the milk through cadmium specific column.

\section{Acknowledgement}

The authors are thankful to the ICAR (NAIP), New Delhi, India for the research grant C4/C10125/2008 supporting this work.

\section{References}

1. Li Y, McCrery DF, Powell JM, Saam H, Jackson-Smith D (2005) A Survey of Selected Heavy Metal Concentration in Wisconsin Dairy Feeds. J Dairy Sci 88: 2911-2922.

2. Li GY, Kim M, Kim JH, Lee MO, Chung JH, et al. (2008) Gene expression profiling in human lung fibroblast following cadmium exposure. Food Chem Toxicol 46: 1131-1137.

3. European Food Safety Authority (2009) Cadmium in food: Scientific opinion of the Panel on Contaminants in the Food Chain. The EFSA Journal 980: 1-139.
4. Bruhn JC, Franke AA (1976) Lead and cadmium in California raw milk. J Dairy Sci 59: 1711-1717

5. Valiukenaite R, Jarmalaite I, Stankeviciene M, Stankevicius H (2005) Review of Heavy Metals in Cow's Milk. Vet Zootec T 29: 51.

6. Patra RC, Swarup D, Kumar P, Nandi D, Naresh R, et al. (2008) Milk trace elements in lactating cows environmentally exposed to higher level of lead and cadmium around different industrial units. Sci Total Environ 404: 36-43.

7. Ragan HA (1977) Effects of iron deficiency on the absorption and distribution of lead and cadmium in rats. J Lab Clin Med 90: 700-706

8. Reeves PG, Chaney RL (2008) Bioavailability as an issue in risk assessment and management of food cadmium: a review. Sci Total Environ 398: 13-19.

9. Tokusoglu O, Aycan S, Akalin S, Kocak S, Ersoy N (2004) Simultaneous differential pulse polarographic determination of cadmium, lead and copper in milk and dairy products. J Agric Food Chem 52: 1795-1799.

10. Verma N, Singh M (2005) Biosensors for heavy metals. Biometals 18: 121-129.

11. Tauriainen S, Karp M, Chang W, Virta M (1998) Luminescent bacterial sensor for cadmium and lead. Biosens. Biosens Bioelectron 13: 931-938.

12. May LM, Russell DA (2003) Novel determination of cadmium ions using an enzyme self assembled monolayer with surface plasmon resonance. Anal Chim Acta 500: 119-125

13. Wu CM, Lin LY (2004) Immobilization of metallothionein as a sensitive biosensor chip for the detection of metal ion by surface Plasmon response. Biosens Bioelectron 20: 864-871.

14. Ogonnczyk D, Tymecki L, Wyzkiewicz I, Koncki R, Glab S (2005) Screenprinted disposable urease based biosensors for inhibitive detection of heavy metal ions. Sens Actuators B Chem 106: 450-454.

15. Chouteau C, Dzyadevyeh S, Durrieu C, Chovelon JM (2005) A bienzymatic whole cell conductometric biosensor for heavy metal ion and pesticide in water samples. Biosens Bioelectron 21: 273-281.

16. Liao VH, Chien M, Tseng Y, Ou K (2006) Assessment of heavy meta bioavailability in contaminated sediments and soils using green fluorescent protein based bacterial biosensors. Environ Pollut 142: 17-23.

17. Haron S, Ray AK (2006) Optical biodetection of cadmium and lead ions in water. Med Eng Phys 28: 978-981.

18. Chong KF, Loh KP, Ang K, Ting YP (2008) Whole cell environmental biosensor on diamond. Analyst 133: 739-743.

19. Lin TJ, Chung MF (2009) Detection of cadmium by a fiber-optic biosenso based on localized surface plasmon resonance. Biosens Bioelectron 24: 1213 1218.

20. Cha T, Guo A, Zhu XY (2005) Enzymatic activity on a chip: The critical role of protein orientation. Proteomics 5: 416-419.

21. Grieshaber D, MacKenzie R, Voros J, Reimhult E (2008) Electrochemica Biosensors - Sensor Principles and Architecture Sensors 8: 1400-1458. 